\title{
Metallic mineral deposits in the Nordic countries
}

1 Division of Ore Geology and Applied Geophysics, Luleå University of Technology, SE-971 87 Luleå, Sweden. E-mail: par.weihed@ltu.se

2 Geological Survey of Finland, PO Box 96, FI-02151 Espoo, Finland.

3 NTNU, NO-7491 Trondheim, Norway.

4 Geological Survey of Denmark and Greenland, Ø. Voldgade 10, DK-1350 Cph., Denmark.

The Nordic countries, including Greenland, have a long tradition in mining. Documented mining dates back to the 8th century $A D$. Today this region is the most important metallic mining district of the European Union. Metals are produced from active mines in all countries except Iceland and related industries are thriving in all countries.

Important ore deposit types include: volcanogenic massive sulphide deposits $(\mathrm{Cu}, \mathrm{Zn}, \mathrm{Pb}, \mathrm{Au}, \mathrm{Ag})$, orogenic gold deposits $(\mathrm{Au})$, layered intrusions (Ni, $P G E, T i \pm V)$, intrusive hosted $C u-A u$, apatite-Fe deposits, $\mathrm{Cr}$ - and anorthosite hosted Ti deposits. Besides these welldocumented deposits, new kinds of deposits are being explored, e.g., iron oxide-copper-gold (IOCG), shale-hosted $\mathrm{Ni}-\mathrm{Zn}-\mathrm{Cu}$ and different types of uranium deposits.

\section{Introduction}

The Fennoscandian Shield, which forms a large part of the Nordic countries (see descriptions elsewhere in this volume), has historically been one of the most active mining areas in Europe. For example, archaeological evidence shows that copper was produced from the Falun mine in the Bergslagen province, Sweden, early in the 8th century AD (Eriksson and Qvarfort, 1996). Since the industrial revolution in the 19th century, numerous iron mines were exploited in Bergslagen and, during the 20th century, mining of both base metals and iron ore started in several new mining districts such as the Skellefte and Northern Norrbotten districts in Sweden, the Vihanti-Pyhäsalmi and Outokumpu districts in Finland, the Pechenga district in Russia, Tellnes and Sulitjelma in Norway, and Ivittuut (Ivigtut) in Greenland. However, Fennoscandia (the Precambrian Shield together with the Caledonides) can still be regarded as under-explored and having a good potential for major new discoveries, as shown by the discovery of metal, industrial mineral and natural stone deposits made every year in the region.

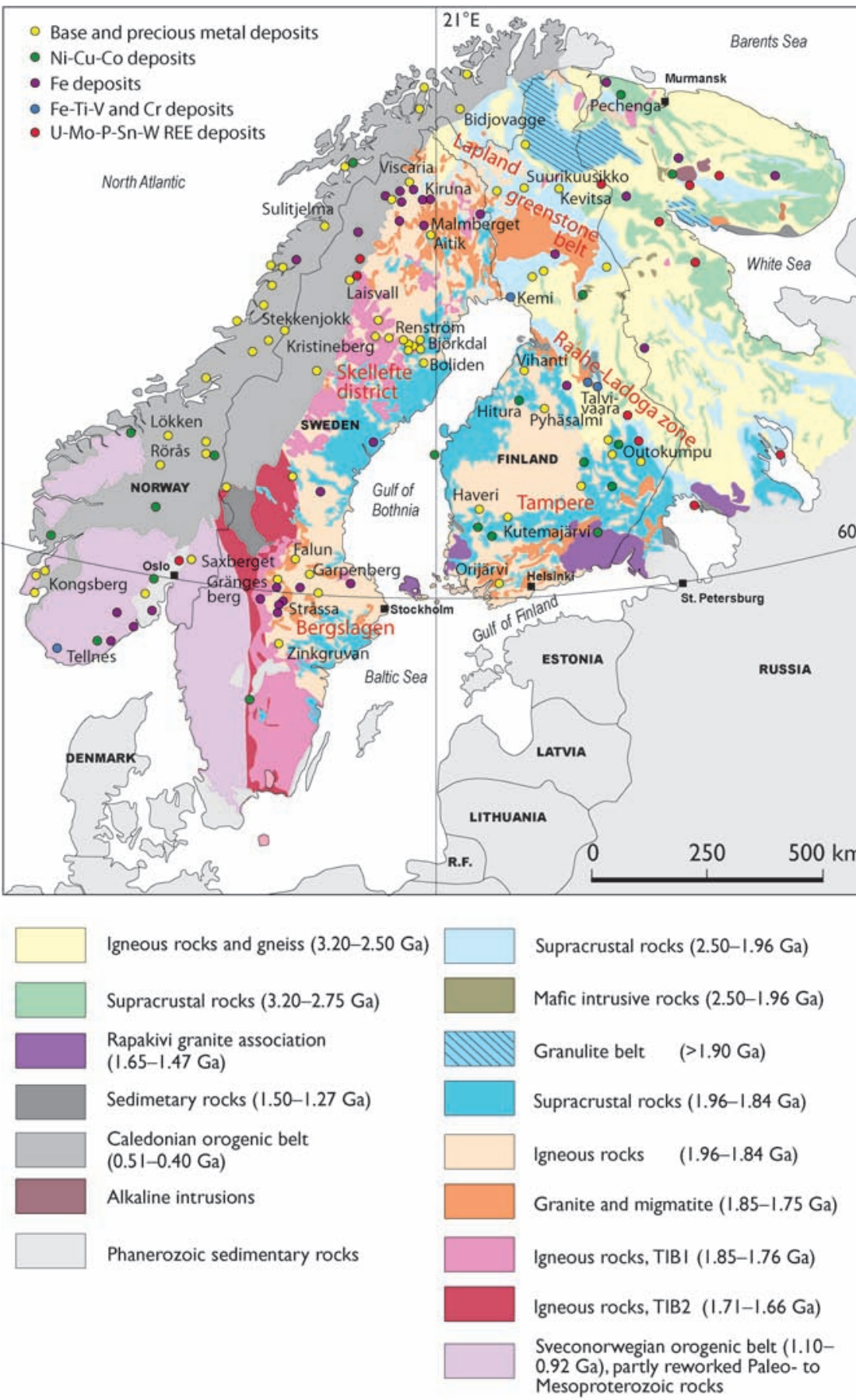

Figure 1 Location of major ore deposits of the Nordic countries. Map from Lahtinen et al. (2005). 


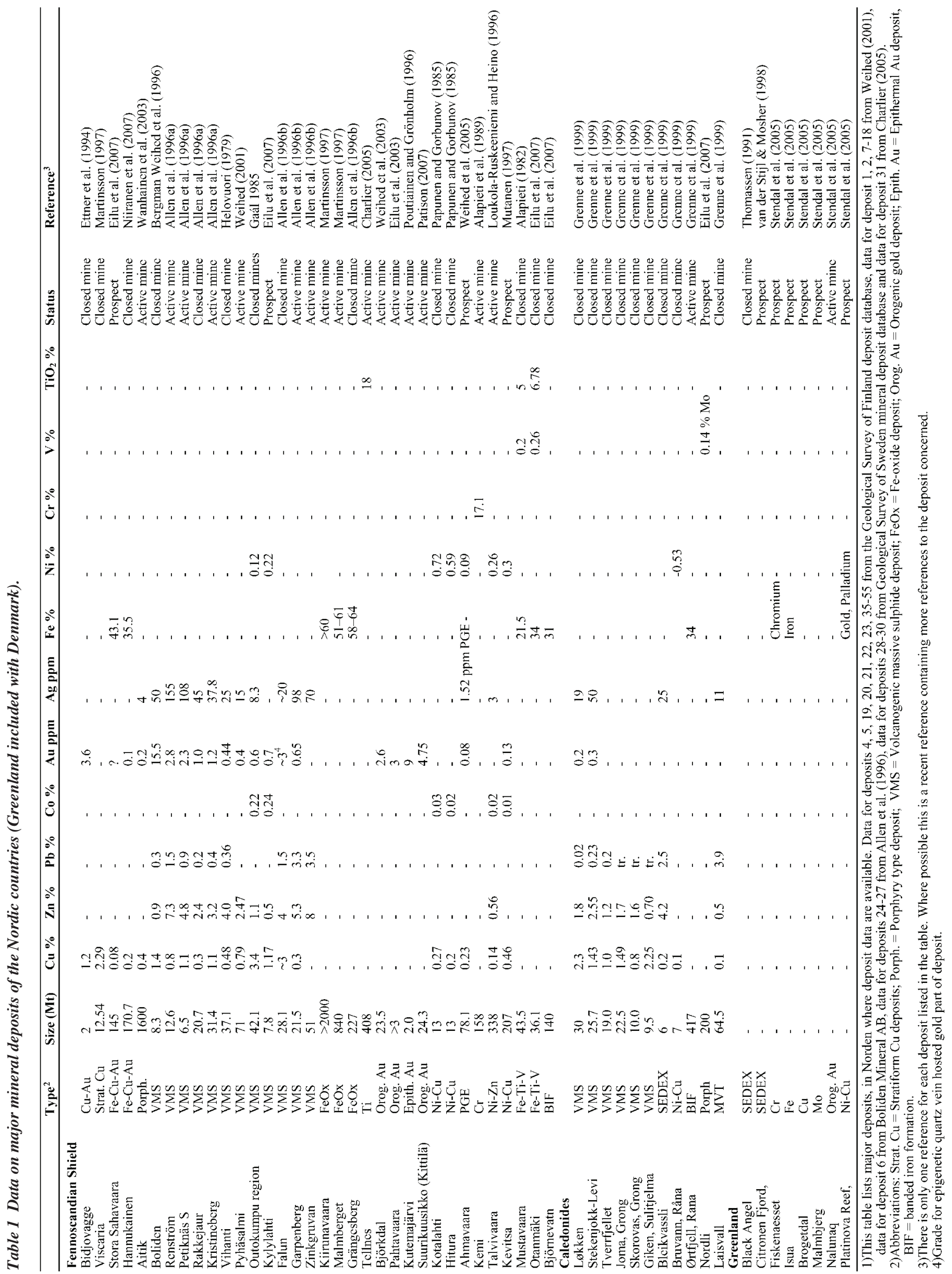


The present economic mineral deposits (Figure 1) are largely concentrated in the Paleoproterozoic parts of the Fennoscandian Shield. Nickel-PGE, orogenic gold, and VMS (including some of uncertain classification), $\mathrm{Pb}-\mathrm{Zn}$, $\mathrm{Cr}$ and $\mathrm{Fe}$-oxide deposits are the main types of economic interest in the Shield (Table 1). Large tonnage-low grade $\mathrm{Cu}$-Au deposits (e.g., Aitik) are associated with intrusive rocks in northern areas. The latter have been described as porphyry style or as hybrid porphyry-IOCG style deposits (Weihed, 2001; Wanhainen et al., 2003). Also Fe-Ti oxides occurring in anorthosites and chromite in layered intrusions are major deposit types in the region. Besides these, mining of tungsten, molybdenum, REE and lithium has taken place during the last decades on smaller scales.

Greenland, with many terranes of Archean and Proterozoic age, is currently also being explored for similar commodities and the first gold mine is now in production. Also the Caledonian orogen hosts many major mineral occurrences in Norway and Sweden. This short review of ore deposit types in the Fennoscandian Shield and their geodynamic setting is chiefly derived from Weihed et al. (2005).

The main metal mining areas in Norden are described below and the metallogeny is put into a geodynamic context.

\section{Greenland}

Greenland's first gold mine, Nalunaq, located in the Nuuk region (Stendal and Secher, 2002) in southern Greenland, was officially opened in August, 2004 (Figure 2). Since the systematic exploration for minerals in Greenland started in the $1800 \mathrm{~s}$, moderate-size to major deposits of chromium, copper, gold, iron, lead, molybdenum, phosphorous, PGE, rare-earth metals, yttrium, silver, and zinc have been discovered but only a few have been mined (Table 1). Exploration for kimberlite pipes, with a potential for diamonds, is being carried out in west-central Greenland, and diamonds have been recovered in two areas (Jensen and Secher, 2004). Mining occurred in the last century at the Mestersvig lead-zinc deposit, the Maarmorilik (Black Angel mine) lead-zinc-silver deposit (Thomassen, 1991), and the Innatsiaq, Josva, and Lillian copper deposits in the Kobbeminebugt. A new exciting discovery, the Citronen Fjord lead and zinc deposit, occurs near the Navarana Fjord Escarpment in north Greenland (Van der Stijl and Mosher, 1998).

Greenstone belts in Greenland are found in both Archean and Paleoproterozoic terranes, where they are generally rather small in volume compared to similar belts in Canada, Australia, and the Fennoscandian Shield. The Greenland Archean gneiss complex, a part of the 3.8-2.5 Ga North Atlantic Craton, contains fragmented belts (maximum 10 vol. \%) of supra-crustal rocks within the gneisses. In addition, within Greenland's granite-greenstone terranes, mafic to ultramafic magmatic intrusions occur hosting major deposits, such as chromitite $( \pm$ PGE) in anorthosites, and gabbro complexes with $\mathrm{V}$ and $\mathrm{Ti}$ in magnetite and ilmenite.

Banded iron formations (BIF), mostly Algoma type, and gold mineralizations are typical for the Archean greenstone belts in Greenland. BIFs occur in three main localities with the most famous in the Isua supracrustal belt $(\sim 3805 \mathrm{Ma})$, and the two others of rather large size, at Itilliarsuk ( 2850 Ma) and Melville Bugt (2700 Ma). The latter locality can be correlated with similar deposits on Baffin Island, Canada, which are subject now to feasibility studies.

Gold is a potential commodity in most of the Archean and some of the Paleoproterozoic greenstone belts and other supracrustal sequences. Most of the known Archean gold occurrences in Green-
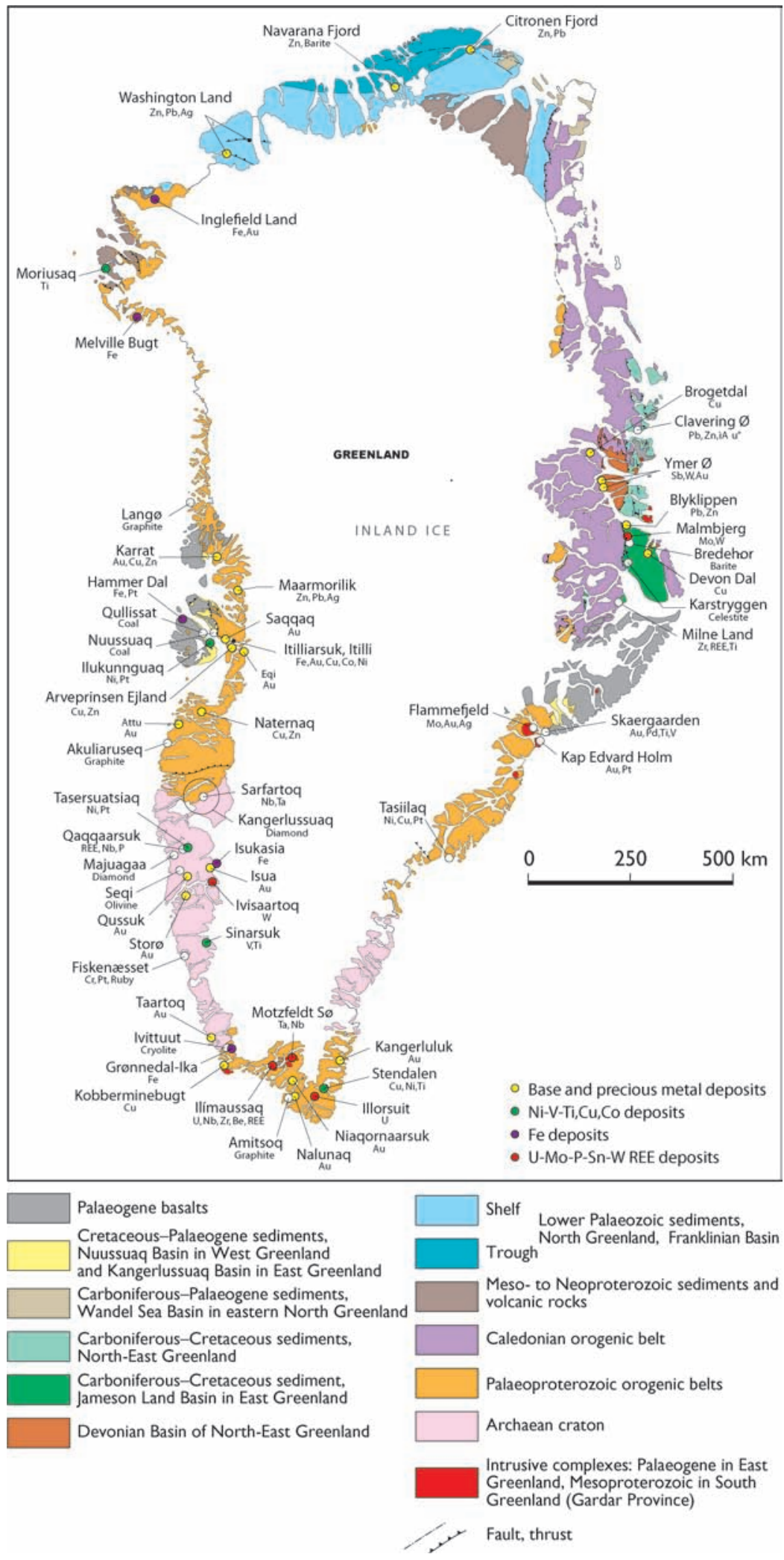

Figure 2 Major metallic mines and prospects in Greenland. Map from Greenland Mineral exploration letter (GEUS, 2007).

land are older than $2.7 \mathrm{Ga}$, and they are all smaller than similar deposits in Canada and Australia. The favourable areas are the southwestern edge of the Mesoarchean block at Sermiligaarsuk fjord within the Tartoq Group greenstone belt, and the Meso-Neoarchean belts in the Nuuk region where there are two interesting areas: One is a Mesoarchaean arc-related system with a $\mathrm{Cu}-\mathrm{Au}$ association (Qussuk), and the other is on Storø with a typical As-rich orogenic 
gold-style mineralisation. To the north of the Archean block, the Paleoproterozoic mobile belts contain large amounts of reworked Archean rocks and Proterozoic intrusions. Within this belt, a Mesoarchean block is preserved in the northeastern part of Disko Bugt area containing both stratabound and orogenic types of gold deposits (Stendal and Garde, 2005; Stendal et al., 2007).

The juvenile Ketilidian orogen is considered to be a gold province with several prospects in different settings and the only gold mine in Greenland. The gold is thought to be related to the later stages of a batholith intrusion (1800-1770 Ma), but is found both in supracrustal rocks and granitoids (Stendal and Frei, 2000). The greenstone belts in the Paleoproterozoic domains outside South Greenland are at present considered to have a low potential for gold deposits. Supracrustal suites in the northern Nagssugtoqidian orogen (1950-1920 Ma) contain syngenetic massive sulphide occurrences (Naternaq and Ataneq), and the Ataneq area contains prominent graphite deposits. The Karrat Group comprises the SEDEX-style Black Angel deposit (Thomassen, 1991) and sulphide-gold occurrences at Karrat Isfjord. In Inglefield Land gold mineralisation is related to shear zones and hosted by Paleoproterozoic deformed gneisses and supracrustal rocks (Stendal et al., 2005).

Mineral occurrences in Greenland's magmatic environments are very promising, with giant porphyry molybdenum deposits related to a Paleogene alkaline intrusion in East Greenland and associated vein systems with gold and silver. Another giant deposit is the Skaergaard gabbroic intrusion containing a world-class deposit of Au, Pd, Pt, V and ilmenite. Except around known deposits, the Paleogene alkaline and mafic igneous rocks in East and West Greenland are, in general, frontier areas, providing optimism for the discovery of new deposits.

The alkaline Mesoproterozoic intrusions in the Gardar province contain large deposits of niobium, tantalum, zirconium, rare earth elements, and cryolite. Of these, the eudialite (zirconium) deposit at Ilimaussaq ('Kringlerne') has been thoroughly investigated. Within Greenland's Mesoproterozoic magmatic province an equivalent to the Voisey's Bay deposit in Labrador has still to be found. The carbonatites of both Neoproterozoic and Jurassic age have a great potential for niobium, tantalum, REE and apatite. The Neoproterozoic kimberlite dykes and sills in the Kangerlussuaq area have promising diamond potential and are currently under exploration (Stendal et al., 2005).

Examples of sediment-hosted mineralizations are: (1) copper in Neoproterozoic and Triassic sandstones, (2) lead and zinc in shale/carbonate sequences, (3) fossil placer deposits and evaporite deposits and (4) lead-zinc veins in sediments in the Mesters Vig area in East Greenland, including the closed Blyklippen $\mathrm{Pb}-\mathrm{Zn}$ mine.

SEDEX-type $\mathrm{Pb}-\mathrm{Zn}$ deposits in shale sequences are found in the sedimentary basin in North Greenland. Carbonate-hosted $\mathrm{Pb}$ $\mathrm{Zn}$ (MVT) is known from platform carbonates both in North and East Greenland. Celestite and barium deposits are related to basins with evaporites in East Greenland. Many of the sedimentary basins are situated in remote areas and are still frontier regions with respect to exploration. The geological setting in these remote areas is highly favourable for SEDEX- and MVT-type deposits (Stendal et al., 2005)

\section{Fennoscandian Shield}

\section{Ni-Cu-PGE deposits}

$\mathrm{Ni}-\mathrm{Cu} \pm \mathrm{PGE}$ deposits occur in several different settings within the Fennoscandian Shield (Weihed et al., 2005 and references therein). Nickel has been and still is mined on a large scale in northwestern Russia, (e.g., Pechenga) and Finland (e.g., Kotalahti, Hitura and Vammala) and to a lesser extent in Sweden (e.g., Lainejaur). The age and geodynamic setting of these deposits can be subdivided into: (1) Archean greenstone belts $(2.74 \mathrm{Ga}),(2)$ older Paleoproterozoic (2.49-2.45 Ga) mafic layered intrusions in Finland and Russia, also containing large $\mathrm{Cr}$ deposits and stand-alone PGE deposits, akin to Bushveld, (3) younger Paleoproterozoic (2.2 to $2.05 \mathrm{Ga}$ ) greenstone belts, (4) Paleoproterozoic ophiolite complexes $(1.97 \mathrm{Ga}),(5)$ rift-related ultramafic volcanism (1.97 Ga), (6) Svecofennian orogenic mafic-ultramafic intrusions $(1.88 \mathrm{Ga})$, and $(7)$ post-orogenic diabase dykes.

\section{VMS deposits}

Volcanogenic massive sulphide (VMS) deposits are currently the most exploited base metal ore type in the Fennoscandian Shield. Five deposits are currently mined in the Skellefte district in northern Sweden, one in the Pyhäsalmi area in central Finland and two in the Bergslagen region of south-central Sweden. However, it is unclear (as discussed below) whether or not some of the major deposits in the Bergslagen region should be classified as VMS deposits (e.g., Garpenberg and Zinkgruvan). Also an open question is whether or not the Outokumpu deposits (Kontinen, 1998; Sorjonen-Ward et al., 2004) really are VMS deposits sensu stricto. Significant VMS potential also exists in the northern Paleoproterozoic supracrustal belts, as shown by the now closed Viscaria and Pahtavaara $\mathrm{Cu}-\mathrm{Zn}$ mines in Sweden and Finland, respectively.

\section{Orogenic gold}

Most of the gold occurrences of the Fennoscandian Shield belong to the orogenic category, following the terminology of Groves et al. (1998). These are present in practically all Archean and Proterozoic supracrustal belts. Some gold deposits have been described with alternative genetic models. For example, Enåsen (Hallberg, 1994) and Kutemajärvi (Poutiainen and Grönholm, 1996) have been interpreted as metamorphosed epithermal deposits. Today's largest gold deposit in the Fennoscandian Shield, Boliden, has also been described as a hybrid epithermal VMS deposit (Bergman Weihed et al., 1996). In the northernmost part of the Fennoscandian Shield, $\mathrm{Cu}-\mathrm{Au}$ ores, such as Bidjovagge (Ettner et al., 1994), Pahtohavare (Lindblom et al., 1996) and Saattopora (Grönholm, 1999), have been described as orogenic gold deposits, although their high $\mathrm{Cu}$ content and saline mineralising fluids are more akin to IOCG deposits (Weihed, 2001; Eilu et al., 2003).

Almost all currently economic deposits are in the Paleoproterozoic domains (Sundblad, 2003). The apparent scarcity of Archean economic deposits may be due to the paucity of exploration for gold in the Russian part of the Shield, and that all gold exploration is recent within the region; also that the largest greenstone belt of the Shield (the Central Lapland greenstone belt) is Paleoproterozoic in age.

Age data on orogenic gold mineralizing events are scarce, but it is possible to constrain three major periods of mineralization: 2.72 to $2.67 \mathrm{Ga}, 1.90$ to $1.86 \mathrm{Ga}$ and 1.85 to $1.79 \mathrm{Ga}$ (Eilu and Weihed, 2005). The age data appear to define a rough zonation from northeast to southwest, which seems to be related to the southwestward growth of the Fennoscandian Shield with time.

Recent discoveries of orogenic gold deposits include the "Gold line" in northern Sweden with two active mines (Svartliden and Blaiken, currently in January 2008 the Blaiken deposit is put on hold due to technical and economic difficulties) and one deposit (Fäbodliden) in the feasibility stage. Suurikuusikko, in the Central Lapland greenstone belt of Finland, with a current in situ resource of 115 gold, is the largest deposit in northern Europe and will start production in 2008 (Patison, 2007).

\section{Fe deposits (including IOCG), porphyry $\mathrm{Cu}-\mathrm{Au}$ and stratiform $\mathrm{Cu} \pm \mathrm{Au}$}

The northern Paleoproterozoic part of the Fennoscandian Shield, including parts of Finland, Norway and Sweden, is an economically important metallogenic province dominated by Fe oxide and $\mathrm{Cu} \pm \mathrm{Au}$ ores. Based on the style of $\mathrm{Fe}$ and $\mathrm{Au}-\mathrm{Cu}$ mineralization and the extensive albite and scapolite alteration, the region has been regarded as a typical IOCG province (e.g., Martinsson, 2001; Williams et al., 2003; Niiranen et al., 2007). Four major types of deposits exist, namely skarn-like $\mathrm{Fe} \pm \mathrm{Cu} \pm \mathrm{Au}$ deposits, Kiruna type Fe oxides (apatite iron ores), and epigenetic and porphyry style $\mathrm{Cu} \pm \mathrm{Au}$ and $\mathrm{Au}$ deposits. In strictly genetic terms, only some of these can be classified as typical iron oxide-Cu-Au (IOCG) deposits, whereas others only share a few characteristic features with this, rather loosely defined, ore class (cf. Hitzman et al., 1992; Hitzman, 
2000). For example, the Kiruna-type deposits could also be interpreted as magmatic, or magmatic-hydrothermal occurrences (Nyström and Henriquez, 1994).

Economically, the most important deposit type for the region is the apatite-iron ore, presently with an annual production of about $31 \mathrm{Mt}$ of ore from the Kiirunavaara and Malmberget mines and a total production of about 1,600 Mt from 10 mines during the last 100 years. Copper and gold have been mined on a large scale in Sweden (Aitik), whereas other $\mathrm{Cu}-\mathrm{Au}$ mines (e.g., Bidjovagge, Saattopora) have been small. All of the sulphide deposits are hosted by Paleoproterozoic greenstones and are small- to medium-sized except for Aitik, which occurs in Svecofennian volcaniclastic rocks and is a world-class deposit with a total resource of $>1,000 \mathrm{Mt}$ and an annual production of $18 \mathrm{Mt}$. At present, Aitik is seen as a porphyry-style deposit possibly with a subordinate IOCG-style overprint (Wanhainen et al., 2003).

The Bergslagen region in south-central Sweden, and its extension in southwestern Finland, hosts a number of $\mathrm{Fe}$ deposits of various types. Currently there is no mining of Fe in this historically important iron province (e.g., major deposits like Grängesberg and Dannemora), but the recent increase in metal prices has led to a feasibility study to reopen the Dannemora mine. Also the Stora Sahavaara IOCG-style (?) Fe deposit in northern Sweden is currently being investigated, together with similar deposits in the neighbouring Kolari area in Finland.

\section{Fe-Ti oxides in anorthosites}

Magmatic ilmenite deposits are typically hosted by anorthosite massifs. The second largest deposit of this type in the world is the Tellnes ilmenite norite deposit which was intruded into the central part of the Neoproterozoic Ana-Sira anorthosite massif, in the Rogaland Anorthosite Province of southwestern Norway (Bingen and Stein, 2003). Smaller Fe-Ti occurrences are widespread in the area. Among them, the most important are Storgangen and Blåfjell (Duchesne, 1999), but mining activities are currently confined to Tellnes where the average grade is slightly above $18 \% \mathrm{TiO}_{2}$ for $>380 \mathrm{Mt}$ of ore.

\section{Other deposit types}

Other types of metal occurrences in the Nordic countries include $\mathrm{Cr}, \mathrm{Li}, \mathrm{Mo}, \mathrm{Nb}, \mathrm{REE}, \mathrm{Sn}, \mathrm{Ta}, \mathrm{W}$ and $\mathrm{U}$. The Kemi chromite mine in Finland is one of the largest chromium deposits in Europe. Recent promising exploration results include the $340 \mathrm{Mt}$ Talvivaara Ni-Cu$\mathrm{Zn}$ deposits hosted by metamorphosed black shales in the Paleoproterozoic Kainuu Schist Belt, Finland (www.talvivaara.com; Eilu et al., 2007). Talvivaara is an example of a previously unexploited style of mineralization which may prove, globally, to be a major new source for base metals.

During the last decade, diamond exploration has been successful in delineating diamondiferous kimberlite pipes especially in the Archangelsk area in Russia, but also in the eastern Finland (see http://en.gtk.fi/ExplorationFinland/Commodities/Diamonds.html).

Uranium is known to occur in several mineralization types in both vein-type deposits in Precambrian rocks, primarily in Finland and in Paleozoic shales overlying the Precambrian basement in Sweden. Substantial low-grade reserves are known in Cambrian alum shales (Wilson, 1979; Andersson et al., 1985; Gustafsson, 2007). Many of these deposits are now being investigated, although it is uncertain whether or not mining of uranium will be permitted in Sweden or Finland.

\section{Caledonide metallogeny}

The Caledonide nappe complexes in western Fennoscandia contain several major ore deposit types, some of world-class dimensions. In the post-world war era, massive $\mathrm{Cu}-\mathrm{Zn}-\mathrm{Pb}$ sulphide deposits in both volcanic and sedimentary settings comprised the backbone of the mining industry in Norway. The last massive sulphide mine was closed in the mid-1990s and large-scale exploration for new deposits of any kind has been minimal since the 1980s. Currently, the Ørtfjell iron deposit is the only Caledonian metallic deposit being mined.
Systematic exploration and research on Norwegian metallic deposits had a low priority since the mid-1990s, although the diversity of fertile geological terrains and large expanses of mostly unexplored territory provide an incentive for new exploration. Slowly, this situation is changing and currently there is active exploration in both the Fennoscandian Shield and the Caledonides of Norway, although far below the level now observed in Sweden and Finland. Most of the activities in the Caledonides concern hydrothermal gold deposits (e.g., Bindal and Mofjellet), but recently also polymetallic tungsten skarn deposits in the Nordland tungsten province and orthomagmatic $\mathrm{Ni}-\mathrm{Cu}$ deposits in the Caledonides as well as the komatiite lithologies of Finnmark County in the Shield. According to Grenne et al. (1999), the Nordic Caledonian mineral deposits can be subdivided into:

- Stratabound, partly stratiform, massive to disseminated deposits of mainly $\mathrm{Zn}-\mathrm{Pb} \pm \mathrm{Cu}$ sulphides in mixed metasedimentarymetavolcanic successions (Bleikvassli, Mofjellet).

- Stratabound magnetite-hematite deposits in metasedimentary carbonate-pelite successions-so-called metasedimentary iron ores (Ørtfjell).

- Carbonatite-hosted Nb-Fe-P-REE deposits (Fen Complex).

- Organic-rich black shale deposits with concentrations of U, V, Mo, Ni.

- Stratabound, partly stratiform, massive pyritic deposits of $\mathrm{Cu}-\mathrm{Zn}$ $( \pm \mathrm{Pb})$ sulphides (VMS deposits, Stekenjokk-Levi, Lökken, Röros and Sulitjelma).

- Stratabound magnetite-(pyrite-chalcopyrite) deposits (volcanichosted iron ores).

- Orthomagmatic Ni-Cu-S and $\mathrm{Cr}$ deposits with locally high PGE (Bruvann, Råna).

- Minor Cu-Mo stockwork mineralisation in felsic magmatic rocks.

- Stratabound, disseminated to semi-massive accumulations of $\mathrm{Pb} \pm \mathrm{Zn}$ sulphides in quartz-arenites (MVT, sandstone lead deposits, Laisvall).

- Various, small, vein- and replacement type deposits characterised by $\mathrm{Au}, \mathrm{Ag}, \mathrm{Pb}, \mathrm{Zn}, \mathrm{Sb}, \mathrm{As}, \mathrm{W}, \mathrm{Mo}$ or U, in metamorphic and plutonic complexes.

\section{Geodynamic settings from the Archean to the Paleozoic}

Throughout the evolution of the Fennoscandian Shield, the orogenic gold deposits also reflect the orogenic younging of the Shield towards the southwest and west. Most orogenic gold deposits formed during periods of crustal shortening, and the mineralization processes peaked at $2.72-2.67 \mathrm{Ga}, 1.90-1.86 \mathrm{Ga}$, and $1.85-1.79 \mathrm{Ga}$.

Between ca. 2.5 to $2.4 \mathrm{Ga}$, the Archean craton rifted on a large scale, possibly for the first time, facilitating the emplacement of extensive layered intrusions and mafic dyke swarms. At this stage and, to some extent, also during later rifting stages at 2.2 to $2.05 \mathrm{Ga}$, $\mathrm{Ni}-\mathrm{Cu} \pm \mathrm{PGE}$ deposits formed both as part of layered igneous complexes and associated with mafic volcanism in rifted basins with komatiite volcanism in the Karasjokk, Kautokeino and Central Lapland greenstone belts. However, small $\mathrm{Ni} \pm \mathrm{Cu} \pm$ PGE deposits also occur in the Neoarchean greenstone belts of eastern Finland (possibly also in Russia), and also these may be related to rifting of the Archean crust. Synorogenic mafic-ultramafic intrusions formed during the peak of the Svecokarelian orogen at ca. 1.89 to $1.88 \mathrm{Ga}$. These host numerous $\mathrm{Ni}-\mathrm{Cu}$ deposits and are confined to linear belts that slightly post-date the regional arc volcanism.

Nearly all VMS-style deposits in the Fennoscandian Shield formed between 1.97 and $1.88 \mathrm{Ga}$ in extensional settings during basin inversion and accretion. The oldest, the Outokumpu-type $\mathrm{Cu}-\mathrm{Co} \pm \mathrm{Au} \pm \mathrm{Ni} \pm \mathrm{Zn}$ deposits were formed at 1.97-1.95 Ga in mantle rocks that were subsequently obducted onto the Archean continent during onset of convergence. The next, more typical VMS deposits formed at 1.93 to $1.91 \mathrm{Ga}$ in an accreted, primitive, bimodal arc setting which formed during extension of only slightly older volcanic crust in the Pyhäsalmi area in central Finland. Their host rocks are tholeiitic basalts and transitional to calc-alkaline rhyolites, including 
high-silica varieties, and the deposits broadly fit within the "bimodal mafic type" classification of Barrie and Hannington (1999). The Skellefte VMS deposits are 20 to 30 million years younger and Allen et al. (2002) suggest that, in contrast to the deposits in the Pyhäsalmi area, the former district is a remnant of a strongly extensional intraarc region that developed on continental or mature arc crust where the basement was only slightly older. The Bergslagen-Uusimaa belt, with a much more diverse metallogeny compared to the Skellefte and Pyhäsalmi areas, is coeval with the Skellefte area, but was formed within or at the margin of a microcontinent that collided with Fennoscandia at ca. 1.88 to $1.87 \mathrm{Ga}$. The Bergslagen region is interpreted as an intra-continental extensional or continental margin backarc region developed on older continental crust (Allen et al., 1996b).

IOCG occurrences in the Fennoscandian Shield are diverse in style. At least the oldest mineralizing stages at ca. $1.88 \mathrm{Ga}$ are coeval with magmatism having a monzonitic fractionation trend and calcalkaline to alkaline subaerial volcanism more akin to continental arc, or magmatism inboard of an active arc. There also is evidence for multiple metal introduction or remobilization between ca. 1.80 and $1.77 \mathrm{Ga}$, related to late- to post-orogenic magmatism distal to an active N-S subduction zone further to the west (Weihed et al., 2002). Also, the interaction of magmas with evaporitic sequences in older Paleoproterozoic rift sequences could be significant for forming fluids able to carry large amounts of $\mathrm{Fe}, \mathrm{Cu}$ and $\mathrm{Au}$ (Martinsson, 1997).

Large volumes of anorthositic magmas characterize the Sveconorwegian Orogeny, in the southwestern part of the Fennoscandian Shield. The best example of a major concentration of Ti associated with these anorthosites is the Tellnes deposit. The Tellnes ilmenite deposit belongs to the Mesoproterozoic (930 to $920 \mathrm{Ma}$ ) Rogaland Anorthosite Province in SW Norway. The rocks of this province were emplaced in the southwestern part of the Sveconorwegian orogenic belt under granulite facies conditions, ca. 40 million years after the last regional deformation (Bingen and Stein, 2003). Many massive, but small Ni-Cu sulphide occurrences also formed during emplacement of the anorthosite complexes associated with noritic melts (e.g., the Homsevatn deposit). Otherwise, more important orthomagmatic $\mathrm{Ni}-\mathrm{Cu}$ deposits are associated with the early Sweconorwegian Iveland-Gautestad norite $(1279 \pm 3 \mathrm{Ma})$ in Setesdalen comprising the Flåt Ni-deposit and several smaller occurrences. In addition, sub-economic Mo-occurrences are associated with Sweconorwegian granites, mostly in the southwestern part of this orogenic belt.

Ore deposits associated with the Scandinavian Caledonides may tentatively be divided into three groups: (1) formation during continental rifting and/or ocean floor spreading with emplacement as integral parts of the nappes during the Caledonian orogeny, (2) formation during plate convergence and ocean closure, or (3) formation during continent-continent collision and subsequent extensional orogenic collapse (Grenne et al., 1999). Accordingly, the deposits occur in the accreted Laurentia terrains to the west (now the Uppermost Allochthon), the outboard Iapetus oceanic sequences (Upper Allochthon), the outer continental margin sequences (Upper Allochthon, lower part) and the inner continental margin and shelf successions of Baltica (Middle and Lower Allochthon and Autochthon).

During Neoproterozoic to Cambrian pre-Caledonian divergent tectonics, massive to disseminated volcanosedimentary-hosted Zn$\mathrm{Pb} \pm \mathrm{Cu}$ and $\mathrm{Cu}-\mathrm{Zn}$ sulphide deposits were formed in an Atlantic-type margin environment (Grenne et al., 1999). In the Shield, rift-type tholeiitic to carbonatitic magmatism gave rise to $\mathrm{Nb}, \mathrm{P}$ and $\mathrm{Fe}$ mineralization in carbonatites of the Fen Complex. Late Cambrian epicontinental sedimentation deposited vast, but so far uneconomic resources of $\mathrm{U}, \mathrm{Mo}, \mathrm{Ni}$ and $\mathrm{V}$ in alum shales. Minor stratabound base metal sulphide and orthomagmatic $\mathrm{Cr}$ and $\mathrm{Ni}-\mathrm{Cu} \pm \mathrm{PGE}$ occur only in oceanic environments and continental margin and oceanic successions host many $\mathrm{Cu}-\mathrm{Zn}$ sulphide ores in tholeiitic basalts. The earliest subduction-related sequences of major ore-forming importance are the Early Ordovician Stekenjokk-Fundsjö arc (ca. $490 \mathrm{Ma}$ ) and immature arc and ophiolitic assemblages formed between 500 and $480 \mathrm{Ma}$. In Early to Middle Ordovician times, magmatism gradually changed to a predominantly calc-alkaline character. Major granodiorites intruded the mature-arc sequences at an advanced stage of development (ca. $460 \mathrm{Ma}$ ), occasionally containing sub-economic vein- and stockwork-type $\mathrm{Cu}-\mathrm{Mo}$ mineralisation. By the end of the Ordovician, obduction of the arc-and-arc-basin systems on to the edge of the Laurentian plate took place. Thick clastic sequences were intruded by rift-type, mainly tholeiitic to alkaline, magmas with $\mathrm{Ni}$ $\mathrm{Cu}$ mineralization and stratabound sulphides associated with volcanic rocks. The final, collisional stage of the Caledonian orogeny (Scandian) is represented by MVT-type $\mathrm{Pb}$-sandstone deposits and $\mathrm{Au}, \mathrm{Ag}, \mathrm{Pb}, \mathrm{Cu}, \mathrm{Zn}, \mathrm{Fe}, \mathrm{As}, \mathrm{Sb}, \mathrm{W}, \mathrm{Mo} \pm \mathrm{U}$ vein deposits (Grenne et al., 1999). Post-collisional magmatism is associated with a regional mineralization event in the western parts of the Uppermost Allochthon, characterised by polymetallic W-Mo-Au occurrences (Larsen, 1991; Grenne et al., 1999). Recent Re-Os dating of the Bjellåtinden W-Mo skarn has provided evidence of a long-lived mineralization stage from $430 \pm 5$ to $401 \pm 3 \mathrm{Ma}$, i.e., beginning at Scandian peak metamorphism and continuing through lower-grade extensional shearing (Larsen and Stein, 2007). Also the Målvika W-Mo$\mathrm{Au}$ and the Bindal Au-deposits (currently in test production) belong to this latest Caledonian mineralizing event.

\section{Concluding remarks}

The Fennoscandian Shield is one of the most intensely mineralized Paleoproterozoic areas in the world. Important ore deposit types include volcanogenic massive sulphide deposits, orogenic gold deposits, layered intrusions, intrusive hosted $\mathrm{Cu}-\mathrm{Au}$, apatite-Fe deposits, and anorthosite-hosted $\mathrm{Ti}$ deposits. Currently all these types of deposits are exploited and exploration expenditure is at an all time high level in 2007. Investment in exploration in the Fennoscandian Shield in 2007 will probably be close to 100 million euros. Besides the well documented deposit types, new kinds of deposits are being explored, e.g., iron oxide-copper-gold (IOCG) and shale-hosted $\mathrm{Ni}-\mathrm{Zn}-\mathrm{Cu}$ and different types of uranium deposits. Greenland is still a frontier area concerning mineral exploration and mining, however, present high activity of exploration is promising for the country. Two mines are in operation (gold and olivine) and feasibility studies are in progress for five deposits.

\section{References}

Alapieti, T., 1982, The Koillismaa layered igneous complex, Finland-its structure, mineralogy and geochemistry, with emphasis on the distribution of chromium: Geol. Surv. Finland. Bull., 319.

Alapieti, T., Kujanpää, J., Lahtinen, J.J. and Papunen, H., 1989, The Kemi stratiform chromitite deposit, northern Finland: Economic Geology, v. 84, pp. 1057-1077.

Allen, R.L., Lundström, I., Ripa, M., Simeonov, A., and Christofferson, H., 1996b, Facies analysis of a $1.9 \mathrm{Ga}$., continental margin, back-arc, felsic caldera province with diverse $\mathrm{Zn}-\mathrm{Pb}-\mathrm{Ag}-(\mathrm{Cu}-\mathrm{Au})$ sulfide and $\mathrm{Fe}$ oxide deposits, Bergslagen region, Sweden: Economic Geology, v. 91, pp. 979-1008.

Allen, R.L., Weihed, P. and Svenson, S-A., 1996a, Setting of Zn-Cu-Au-Ag massive sulfide deposits in the evolution and facies architecture of a 1.9 Ga marine volcanic arc, Skellefte district, Sweden: Economic Geology, v. 91, pp. 1022-1053.

Allen, R.L., Weihed, P. and the Global VHMS Research Project team, 2002 Global comparison of volcanic-associated massive sulphide districts, in Blundell, D.J., Neubauer, F., and von Quadt, A., eds, The Timing and Location of Major Ore Deposits in an Evolving Orogen: Geological Society, London, Special Publications, v. 204, pp. 13-37.

Andersson, A., Dahlman, B., Gee, D.G. and Snäll, S., 1985, The Scandinavian alum shales: SGU, ser. Ca, nr 56, pp. 50.

Barrie, C.T., and Hannington, M.D., 1999, Volcanic-associated Massive Sulfide Deposits: Processes and Examples in Modern and Ancient Settings: Reviews in Economic Geology, v. 8, pp. 101-131.

Bergman Weihed, J., Bergström, U., Billström, K., and Weihed, P., 1996, Geology and tectonic evolution of the Paleoproterozoic Boliden $\mathrm{Au}-\mathrm{Cu}-\mathrm{As}$ deposit, Skellefte district, northern Sweden: Economic Geology, v. 91, pp. 1073-1097.

Bingen, B. and Stein, H.J., 2003, Molybdenite Re-Os dating of biotite dehydration melting in the Rogaland high-temperature granulites, S Norway: Earth and Planetary Science Letters, v. 208 , pp. 181-195.

Charlier, B., 2005, Box 8-4: Fennoscandian Shield-Rogaland Anorthosite Province. Tellnes ilmenite deposit: Ore Geology Reviews, v. 27, pp. 330-331.

Duchesne, J.C., 1999, Fe-Ti deposits in Rogaland anorthosites (South Norway): geochemical characteristics and problems of interpretation: Mineralium Deposita, v. 34, pp.182-198. 
Eilu, P. and Weihed, P., 2005, Fennoscandian Shield - orogenic gold deposits: Ore Geology Reviews, Ore Geology Reviews, v. 27, pp. 326-327.

Eilu, P., Sorjonen-Ward, P., Nurmi, P. and Niiranen, T., 2003, A review of gold mineralization styles in Finland: Economic Geology, v. 98, pp. 1329-1353

Eilu, P., Hallberg, A., Bergman, T., Feoktistov, V., Korsakova, M., Krasotkin, S., Lampio, E., Litvinenko, V., Nurmi, P.A., Often, M., Philippov, N., Sandstad, J.S., Stromov, V. and Tontti, M. 2007, Fennoscandian Ore Deposit Database - explanatory remarks to the database: Geological Survey of Finland, Report of Investigation, v. 168, 19 pp. Database available online at: http://en.gtk.fi/ ExplorationFinland/FODD.

Eriksson, J.A., and Qvarfort, U. 1996, Age determination of the Falu Coppermine by ${ }^{14} \mathrm{C}$-datings and palynology: GFF, v.118, pp. 43-47.

Ettner, D.C., Bjørlykke, A., and Andersen, T., 1994, A fluid inclusion and stable isotope study of the Proterozoic Bidjovagge $\mathrm{Au}-\mathrm{Cu}$ deposit, Finnmark, northern Norway: Mineralium Deposita, v. 29, pp. 16-29.

Gaál, G., 1985, Nickel metallogeny related to tectonics, in Papunen, H. and Gorbunov, G. I,. eds, Nickel-copper deposits of the Baltic Shield and Scandinavian Caledonides. Geological Survey of Finland. Bulletin, v. 333, pp. 143- 155.

GEUS 2007, Greenland mineral exploration letter 30.

Grenne, T., Ihlen, P.M. and Vokes, F.M., 1999, Scandinavian Caledonide Metallogeny in a plate tectonic perspective: Mineralium Deposita, v. 34, pp. 422-471.

Groves, D.I., Goldfarb, R.J., Gebre-Mariam, M., Hagemann, S., and Robert, F., 1998, Orogenic gold deposits: A proposed classification in the context of their crustal distribution and relationship to other gold deposit types: Ore Geology Reviews, v. 13, pp. 1-28.

Grönholm, P., 1999, The mesothermal Saattopora copper-gold deposit in the Palaeoproterozoic Central Lapland greenstone belt, Northern Finland, in Cook, N.J., Sundblad, K. eds, Precambrian Gold in the Fennoscandian and Ukrainian Shields and Related Areas. Gold '99 Trondheim, Norway, 4-6 May 1999: Geological Survey of Norway, Trondheim, p. 83.

Gustafsson, B., 2007. Uran i Sverige: Geologiskt forum , v. 55, pp. 30-32.

Hallberg, A., 1994, The Enåsen gold deposit, central Sweden. 1. A Paleoproterozoic high sulphidation epithermal gold mineralization: Mineralium Deposita, v. 29, pp.150-162.

Helovuori, O., 1979, The geology and zinc-copper deposits of the PyhäsalmiPielavesi district, Finland. Economic Geology, v. 74, pp. 1084-1101.

Hitzman, M.W., 2000, Iron oxide-Cu-Au deposits: what, where, when, and why, in Porter, T.M. ed, Hydrothermal Iron Oxide Copper-Gold and Related Deposits: A Global Perspective. Australian Mineral Foundation, Adelaide, pp. 9-25.

Hitzman, M.W., Oreskes, N., and Einaudi, M.T. 1992, Geological characteristics and tectonic setting of Proterozoic iron oxide (Cu-U-Au-REE) deposits: Precambrian Research, v. 58, pp. 241-287.

Huhma, H., Mänttäri, I., and Vaasjoki, M., 1999, Dating the Finnish Archaean greenstone belts - isotope geology, in Papunen, H., Eilu, P. eds, Geodynamic Evolution and Metallogeny of the Central Lapland, Kuhmo and Suomussalmi Greenstone Belts, Finland. Joint Field Excursion and Workshop of GEODE, 11-16. September 1999, abstracts, pp. 72-74.

Jensen, S.M. and Secher, K. 2004, Investigating the diamond potential of southern West Greenland: Geological Survey of Denmark and Greenland Bulletin, v. 4, pp. 69-72.

Kontinen, A., 1998, The nature of the serpentinites, associated dolomite-skarn-quartz rocks and massive $\mathrm{Co}-\mathrm{Cu}-\mathrm{Zn}$ sulphide ores in the Outokumpu area, eastern Finland, in Hanski, E., Vuollo, J. eds, International Ophiolite Symposium and Field Excursion - Generation and Emplacement of Ophiolites Through Time, August 10-15, 1998, University of Oulu, Oulu, Finland: Abstracts-Excursion Guide. Geological Survey of Finland, Special Paper, v. 26, p. 33

Kurki, J. and Papunen, H., 1985, Geology and nickel-copper deposits of the Kianta area, Suomussalmi: Geological Survey of Finland, Bulletin, v. 333, pp. $155-164$.

Lahtinen, R., Korja, A. and Nironen, M., 2005, Palaeoproterozoic tectonic evolution, in Lehtinen, M, Nurmi, P. and Rämö, O.T., eds, Precambrian Geology of Finland-Key to the evolution of the Fennoscandian Shield. Developments in Precambrian Geology, v. 14, Elsevier B.V., Amsterdam, ISBN 13: 978044451421 9, pp 481-532.

Larsen, R.B., 1991, Tungsten skarn mineralisations in a regional metamorphic terrain in Northern Norway: a possible metamorphic ore deposit: Mineralium Deposita, v. 26, pp. 281-289.

Larsen, R.B. and Stein, H.J., 2007, Re-Os dating of W-Mo deposits in the MidNorwegian Caledonides: Abstract, Geological Society of America, Annual Meeting, Denver.

Lindblom, S., Broman, C., and Martinsson, O., 1996, Magmatic-hydrothermal fluids in the Pahtohavare $\mathrm{Cu}-\mathrm{Au}$ deposit in greenstone at Kiruna, Sweden: Mineralium Deposita, v. 31, pp. 307-318.

Loukola-Ruskeeniemi, K. and Heino, T., 1996, Geochemistry and genesis of the black shale-hosted $\mathrm{Ni}-\mathrm{Cu}-\mathrm{Zn}$ deposit at Talvivaara, Finland: Economic Geology, v. 91, pp. 80-110.

Martinsson O., 1997, Paleoproterozoic greenstones at Kiruna in northern Sweden: a product of continental rifting and associated mafic-ultramafic volcanism, in Martinsson, O., Tectonic setting and metallogeny of the Kiruna Greenstones: Ph. D. Thesis Luleå University of Technology, Sweden.1997:19, Paper I, 49 pp.

Martinsson, O., 2001, Diversity and character of apatite iron ores and their relation to epigenetic $\mathrm{Cu}-\mathrm{Au}$ deposits in the Norrbotten $\mathrm{Fe}-\mathrm{Cu}-\mathrm{Au}$ province, northern
Sweden. GSA Annual Meeting, Special session: Iron-Oxide(-CopperGold) Systems - Deposit Studies to Global Context, Boston 4 November 2001, GSA Website Abstracts with Programs 33, http://gsa.confex.com/ gsa/2001AM/finalprogram/abstract_26785.htm

Mutanen, T., 1997, Geology and ore petrology of the Akanvaara and Koitelainen mafic layered intrusions and the Keivitsa-Satovaara layered complex, northern Finland: Geol. Surv. Finland. Bull., v. 395. 233 pp.

Niiranen, T., Poutiainen, M., and Mänttäri, I., 2007. Geochemistry, alteration, fluid inclusion characteristics, and $\mathrm{U}-\mathrm{Pb}$ age data on the iron oxide- $\mathrm{Cu}-\mathrm{Au}$ deposits in the Kolari region, northern Finland: Ore Geology Reviews, v. 30, pp. 75-105.

Nyström J.O. and Henriquez F., 1994, Magmatic features of iron ores of the Kiruna type in Chile and Sweden: ore textures and magnetite geochemistry. Economic Geology 89, pp. 820-839.

Papunen, H. and Gorbunov, G.I., 1985, Nickel-copper deposits of the Baltic Shield and Scandinavian Caledonides: Geological Survey of Finland, Bulletin, v. 333, 394 pp.

Papunen, H. and Vorma, A., 1985, Nickel deposits in Finland, a review, in Papunen, H. and Gorbunov, G.I. eds, Nickel-copper deposits of the Baltic Shield and Scandinavian Caledonides: Geological Survey of Finland, Bulletin, v. 333, pp. 123-143

Patison, N., 2007, Day 3, Stop 1 Suurikuusikko gold deposit: Geological Survey of Finland, Guide, v. 54. pp. 55-62.

Poutiainen, M. and Grönholm, P., 1996, Hydrothermal fluid evolution of the Paleoproterozoic Kutemajärvi gold telluride deposit, Southwest Finland: Economic Geology, v. 91, 1335-1353.

Sorjonen-Ward, P., Ord, A., Kontinen, A., Alt-Epping, P., Zhang, Y., and Kuronen, U., 2004, Geological constraints and numerical simulations of the formation and deformation of the Outokumpu $\mathrm{Cu}-\mathrm{Co}-\mathrm{Ni}-\mathrm{Zn}$-Au deposits, in Muhling, J. et al., eds, Predictive Mineral Discovery under Cover: Extended Abstracts, SEG 2004. 27 September-1 October 2004. Perth, Western Australia. Centre for Global Metallogeny, The University of Western Australia. Publication, v. 33, pp. 285-288.

Stendal, H. and Frei, R., 2000, Gold occurrences and lead isotopes in Ketilidian Mobile Belt, South Greenland: Transactions Institution of Mining and Metallurgy, v. 109, pp. B6-B13.

Stendal, H. and Secher, K., 2002, Gold mineralisation and gold potential in South Greenland: Geology \& Ore 1/2002. GEUS, BMP \& GRAS, 12 pp.

Stendal, H. and Garde, A.A., 2005, Precambrian mineralising events in central West Greenland $\left(66^{\circ}-70^{\circ} 15^{\prime} \mathrm{N}\right)$ : Geological Survey of Denmark and Greenland Bulletin, v. 7, pp. 61-64.

Stendal, H., Secher, K., and Stensgaard, B.M., 2007, Greenstone belts in Greenland and related occurrences - possible counterparts in North America and Fennoscandia, in Andrews, C.J. et al., eds, Proceedings of the Ninth Biennial Meeting of the Society for Geology Applied to Mineral Deposits, Dublin 2007. Dublin: Irish Association for Economic Geology, pp. 939-942.

Stendal, H., Secher, K., Nielsen, B.M., Schønwandt, H.K., and Thorning, L., 2005, Greenland geological environments and mineral resources: Danmarks og Grønlands Geologiske Undersøgelse Rapport 2005/8, 211 pp.

Sundblad, K., 2003, Metallogeny of Gold in the Precambrian of Northern Europe: Economic Geology, v. 98, pp. 1271-1290.

Thomassen, B., 1991, The Black Angel lead-zinc mine 1973-90: Rapport Grønlands Geologiske Undersøgelse, v. 152, pp. 46-50.

van der Stijl, F.W. and Mosher, G.Z., 1998, The Citronen Fjord massive sulphide deposit, Peary Land, North Greenland: discovery, stratigraphy, mineralization and structural setting: Geology of Greenland Survey Bulletin, v. 179, 40 pp.

Vanhanen, E., 2001, Geology, mineralogy and geochemistry of the Fe-Co-Au(U) deposits in the Paleoproterozoic Kuusamo Schist Belt, northeastern Finland: Geological Survey of Finland, Bulletin, v. 399. 229 pp.

Wanhainen, C., Broman, C., and Martinsson, O., 2003, The Aitik Cu-Au-Ag Deposit in Northern Sweden: A Product of High Salinity Fluids: Mineralium Deposita, v. 38, pp. 715-726.

Weihed, P., 2001, A review of Palaeoproterozoic intrusive hosted $\mathrm{Cu}-\mathrm{Au}-\mathrm{Fe}-$ oxide deposits in northern Sweden: Sveriges Geologiska Undersökning C, v. 833 , pp. 4-32.

Weihed, P., Billström, K., Persson, P.-O., and Bergman Weihed, J., 2002, Relationship between $1.90-1.85 \mathrm{Ga}$ accretionary processes and $1.82-1.80 \mathrm{Ga}$ oblique subduction at the Karelian craton margin, Fennoscandian Shield: GFF, v. 124, pp. 163-180

Weihed, P., Bergman Weihed, J., and Sorjonen-Ward, P., 2003, Structural evolution of the Björkdal gold deposit, Skellefte district, northern Sweden Implications for early Proterozoic mesothermal gold in the late stage of the Svecofennian orogen: Economic Geology, v. 98, pp. 1291-1309.

Weihed, P., Arndt N., Billström, K., Duchesne, J.-C., Eilu, P., Martinsson, O. Papunen, H., and Lahtinen R., 2005, Precambrian geodynamics and ore formation: the Fennoscandian Shield: Ore Geology Reviews, v. 27, pp. 273-322.

Williams, P.J., Guoyi, D., Pollard, P.J., Broman, C., Martinsson, O., Wanhainen, C., Mark, G., Ryan, C.G., and Mernagh, T.P., 2003, The nature of iron oxide-copper-gold ore fluids. Fluid inclusion evidence from Norrbotten (Sweden) and the Cloncurry district (Australia), in Eliopoulos, D.G. et al., eds, Mineral Exploration and Sustainable Development: Millpress, Rotterdam, pp. 1127-1130.

Wilson, M.R., 1979, Uranium in Sweden excursion guide 8-13 September 1979: SGU, brap 79037 
Pär Weihed is professor in ore geology and head of the Department of Chemical Engineering and Geosciences at Luleå University of Technology, Sweden. He is currently president of the Geological Society of Sweden, an elected member of the Royal Swedish Academy of Engineering, a fellow of Society of Economic Geologist, where he also acts on the editorial board of Economic Geology, and he is a councillor of SGA (Society of Geology Applied to Mineral deposits). His research interest includes VMS, Orogenic gold and intrusive hosted $\mathrm{Cu}$-Au deposits as well as regional metal-logeny and tectonic evolution of the Fennoscandian Shield.

Pasi Eilu is Senior Geoscientist in South Finland Office of Geological Survey of Finland. Docent in economic geology at Department of Geology in the University of Turku, Finland. Main interests: gold mineralisation, hydrothermal alteration, geochemical dispersion related to ores, metallogeny. Membership of professional bodies: Society for Geology Applied for Mineral Deposits (Member of Council), Society of Economic Geologists, IAGOD, GEODE, Geological Society of Finland, Finnish Association of Mining and Metallurgical Engineers, Finnish Society of Engineering Geology.

Rune B. Larsen, associate professor in mineral deposit geology at Department of Geology, Norwegian University of Science and Technology. Chief consultant, Nordic Mining AS. Before 2004, senior geologist at the Geological Survey of Norway. Current research projects in Norway, Greenland and Mozambique. Several publications on granitic pegmatite mineral deposits, PGE-Cu-Ni deposits, fluid-melt interaction processes.

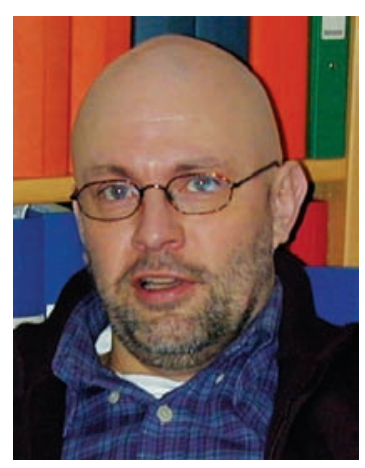

Henrik Stendal is Senior Research Scientist at the Geological Survey of Denmark and Greenland (GEUS). More than 30 years of experience in geochemical exploration, geochemical and ore geological problems. Leader of many projects; lately of the Greenland expeditions to the Nuuk region (2003-2007). Long practise working in remote areas such as Greenland, Norway, Turkey, Ghana, Mozambique, Namibia, Tanzania, Cameroun, Botswana, and Vietnam. Supervised more than 50 M.Sc. students and 10 Ph.D. students at the Universities of Copenhagen and Aarhus during the last 25 years.

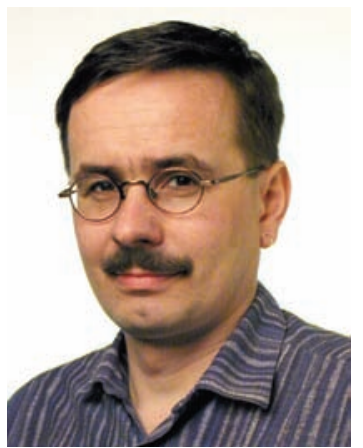

Mikko Tontti is Senior research geologist at the Geological Survey of Finland. He has been working at the survey since 1977, studying mineral deposits and metallogeny, especially of Finland and Scandinavia plus updating, maintaining and developing corresponding ore deposit data bases.
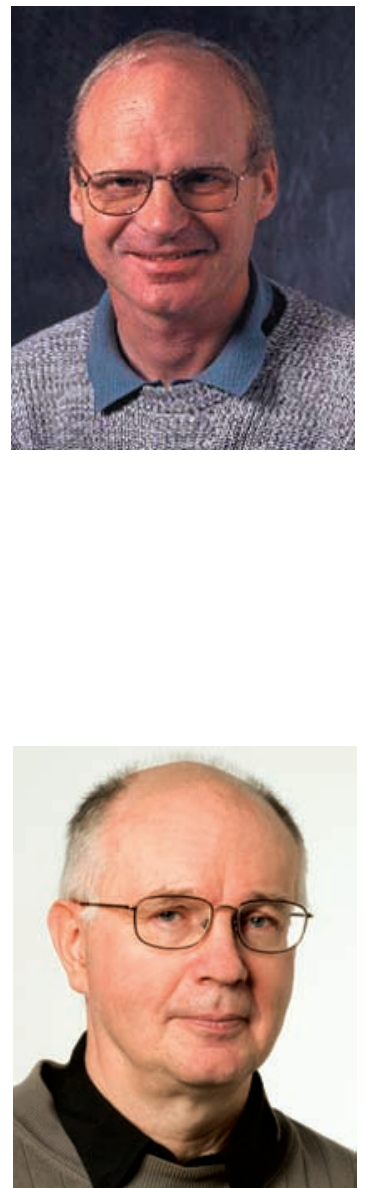

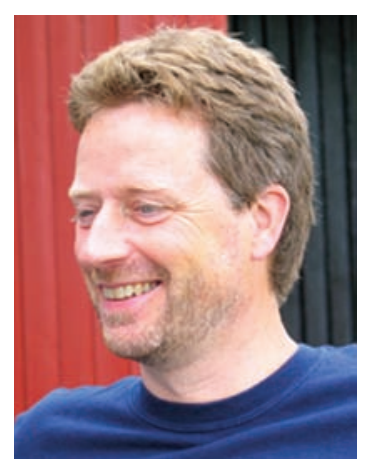

